\title{
THE NORTH AFRICAN "EXTREMISTAN" OF THE ISLAMIC STATE CALIPHATE
}

\author{
Adrian Cosmin BASARABĂ $\breve{A}^{*}$, Maria-Mihaela NISTOR ${ }^{* *}$ \\ *West University of Timișoara,Romania, \\ **Babeş-Bolyai University, Cluj-Napoca, Romania \\ adrian.basaraba@e-uvt.ro, marianistorubb@gmail.com
}

\begin{abstract}
This article aims at presenting ISIS expansion in North Africa in the first quarter of 2016, with its subsequent implication in the wider framework of Jihadist proliferation worldwide. It can be argued that, while losing real estate in the Middle East, ISIS has started a permanent search for extra-cellular matrices or an ongoing process of de-and reterritorialization. The allegiance and support pledged by other African-based terrorist groups or organizations such as Boko Haram, alI'tisam of the Koran and Sunnah in Sudan, al-Huda Battalion in Maghreb of Islam, The Soldiers of the Caliphate, al-Ghurabaa, Djamaat Houmat ad-Da'wa as-Salafiya and al-Ansar Battalion in Algeria, Islamic Youth Shura Council, Islamic State Libya (Darnah), in Libya, Jamaat Ansar Bait alMaqdis, Jund al-Khilafah and Mujahideen Shura Council in the Environs of Jerusalem in Egypt, Okba Ibn Nafaa Battalion, Mujahideen of Tunisia of Kairouan and Jund al-Khilafah in Tunisia and al-Shabaab Jubba Region Cell Bashir Abu Numan in Somalia is an alarming hypothesis of Jihadism reaching "the threshold of inevitability"- syntagm existent in the network theories of David Singh Grewal- turning a whole region, continent of even world into what Nassim Nicholas Taleb would call Extremistan.
\end{abstract}

\section{Keywords: terrorism, ISIS, proliferation, Africa, Libya}

\section{Introduction}

The proliferation of terrorism can no longer be questionable. In the Age of the Network Society, as Manuel Castells would call the contemporary world, borders are permanently redrawn or turned into a perplexing borderlessness and the terrorist organizations are no exception in this respect. Losing real estate at home, the Islamic State (regardless of whether called ISIS or ISIL) can definitely no longer be located solely on the territories of Syria or Iraq.

Despite the fact that the Islamic State (ISIS) Caliphate "shrank by $14 \%$ in 2015 " [1], it must be revealed that their chronicle is still being written, in a more complicated manner, with a permanent search for network cells and knots on other continents. A main argument in this respect is that by December 15, 2015, ISIS had a pledge of allegiance or support to 43 other terrorist organizations [2] in Europe, Asia, Africa and Australia and had had attacks in the Middle East and North Africa, Central Asia, Europe. Furthermore, the January $14^{\text {th }} 2016$ terrorist events in are a conclusive proof of an effective ISIS' expansion in Southeast Asia.

\section{Networking ISIS in (North) Africa}

The African nodes of the ISIS network can actually be considered all the states where certain terrorist groups of 
organizations have pledged allegiance and/ or support to ISIS: Algeria, Egypt, Nigeria, Somalia, Sudan, and Tunisia. As previously mentioned in the abstract of this paper, the most alarming scenario when it comes about the proliferation of terrorist networks is "the threshold of inevitability", meaning that "a network has become so dominant that we can expect virtually all non-users to adopt its standards." [3] In these cases, networks turn into communities that, when sharing extremist views and promulgating them among their members and potential supporters, might become dangerous, since "religious beliefs prepare a kind of landscape of images, an illusory milieu favorable to every hallucination and every delirium." [4]

North Africa is one of the most fertile territories for Jihadist recruitment, regardless of whether one considers the ISIS soldiers, the infantile army used as human shields or the women, in their distinct categories: some raped, others used in all-female battalions, while some of them considered instruments for the creation of a yet unborn army of ISIS child soldiers. Having the highest youth unemployment rate for decades and almost half of the population aged 0-24 years [5], a large share of Muslims that are vulnerable to radicalization, shaken by the Arab spring and its various subsequent changes of governments, with a highly important geographical position in strategic terms, this region has become in the recent years one of the main targets for ISIS (re)location, economic interests primarily in terms of oil, recruitment or stopover on their way to Europe where, cumulated with the rise of extremism in most of the countries, the "organic solidarity", as Durkheim would put it, of the European Union is questioned once again. Whereas the hypotheses of BRexit or EURexit have become more and more debated in the recent months, one should realize that strategic action in the fight against terrorism is imperiously necessary, since there is no such possibility as WORLDexit.

\section{Libya as matrix}

Characterized by omnifarious crises of government and governance, in an optimal geopolitical position to Europe and the Middle East, with the largest African oil reserves, important trans-Saharian smuggling routes and a rising youth unemployment rate of $48.9 \%$, according to the most recent data revealed by the World Bank [6], Libya has become the Africanbased matrix of ISIS.

The UN warnings that "five years since Libya's uprising the security situation continues to deteriorate" [7], "the rise of ISIL in Libya is likely to increase the level of international and regional interference, which could provoke further polarization, if not coordinated" [8] and that "ISIS has been spreading a nationalistic narrative, portraying itself as the most important bulwark against foreign intervention" [9], with an estimated number of ISIS fighters of 5000 to 6000 in March 2016 [10]. The year has started with ISIS being suspected of two attacks on January $7^{\text {th }}$, with a truck bomb resulting in almost 50 casualties near at Libyan Police Academy and a car bombing in the oil port of Ras Lanuf, claiming the latter one, according to Reuters [11].

Worth emphasizing is that Libya is reported to have the largest stockpile of loose weapons in the world plus about 4000 surface to air missiles and 6400 barrels of uranium concentrate powder that could pass into the hands of terrorist groups, which control areas of the country [12].

In terms of hegemony of real estate, even if ISIS has declared its control on three "provinces" in Libya: Tripoli in the west, Barqa (Cyrenaica) in the east, and Fezzan in the southwest [13], much of their dominance focuses on the region of Sirte. The already too fractionated land might be the focal point of spillover terrorist activities in neighboring countries or the stopover towards the EU route via Southern Italy, augmenting the already too problematic refugee crisis that has started to throw Iron Curtains on a Europe that had 
been aimed at encouraging unity and diversity.

\section{ISIS in Libya's neighboring countries}

Whereas the EU actors are more and more divided, ranging from noninterventionist to fully interventionist policies in the fight against terrorism, their 'antagonists" "have shown themselves to be extremely resourceful in collaborating and getting messages to each other" [14] and "the transfer of expertise can be witnessed in the spread of suicide bombings in Libya, Tunisia and Chad and in the growing use of improvised explosive devices in Mali" [15].

A relevant example of the spillover effect of terrorism from Libya to Tunisia can be March $7^{\text {th }}$, when "at least 45 militants, civilians and members of the security forces have been killed in an Islamist attack on the Tunisian town of Ben Guerdane, on the North African nation's frontier with restive Libya." [16] Event if no ISIS-signed terrorist attack has been reported in Algeria, Niger and Chad in the first quarter of 2016, warnings have persisted in the region: in this respect, Colonel Mahamane Laminou Sani, director of documentation and military intelligence for Niger's armed forces declared on February $11^{\text {th }}$ that ISIS was "moving toward southern Libya to avoid the likely air strikes from the European coalition", with further potentially devastating implications for the whole Sahel region [17].

In Egypt, ISIS has claimed responsibility for three attacks in less than two weeks in January: in two different locations, Hurghada (on January $8^{\text {th }}$ ) and Cairo (January $9^{\text {th }}$ and January 21st) [18], [19]. In February, IS affiliate Wilayat Sayna was suspected for two bombings and one shooting incident, whereas in March AlJazeera reports that "the Egyptian government has barred journalists from reporting on events in the troubled Sinai peninsula" [20]. Not only do these terrorist attacks directly affect the population in terms of casualties, wounded and the fear installed; they also have high-reaching implications on the country's economy: "Egypt attracted 346,500 tourists in February 2016, compared to 640,200 last year, according to figures from the Central Agency for Public Mobilisation and Statistics." [21] A drop in tourism of almost $50 \%$ from one year to the other one is rather devastating. Hence, the Daily Mail statement that the well-known resort Sharm El Sheikh has almost turned into a "ghost town" does not seem far-fetched any longer. And the prospects are dim.

Sudan has been used as territory for recruiting British doctors for Syria, but there is a strong likelihood for this target group to be kept on the North African site. Even if the Sudanese Intelligence Chief declared in January that this country would "not be a crossing for Daesh and extremists" and that they would "not tolerate any organized or cross-border crime Sudanese territory is used in" [22], the danger from the neighboring countries and from the inside cannot be ignored.

\section{Conclusion}

This brief analysis of a rather spectacular ISIS evolution in North Africa in the first quarter of 2016, corroborated with the alarming numbers of African-based terrorist organizations that pledged allegiance or support to ISIS, the strongest of which is Boko Haram that formally started to support ISIS via allegiance on March $7^{\text {th }} 2015$, has been used as a case study for ISIS or, generically speaking, Jihadism, going global. While the European Union is divided between a leftist and a farright extremist rhetoric (the latter augmenting itself inherently), the terrorist groups and organizations in North Africa are getting together. In the wider context of the refugee crisis, the attempt at depicting Libya as a new Syria or Iraq is threatening. The currently obvious quantitative and qualitative differences between these states seem to fade away while they are confronted with the imminent threat of 
terrorist proliferation and the drop of almost $50 \%$ in tourism industry from one year to the other one in Egypt, previously mentioned in this article, is just one of the arguments that the world becomes more and more vulnerable to the expansion of terrorism.

\section{References}

[1] http://www.aljazeera.com/news/2015/12/isil-caliphate-shrank-14-percent-2015-monitor151222050249465.html

[2] http://intelcenter.com/maps/is-affiliates-map.html\#gs.tCfZL0c

[3] David Singh Grewal, Network Power: The Social Dynamics of Globalization, New Haven and London, Yale University Press, 2008, p. 40.

[4] Ibidem

[5] https://www.cia.gov/library/publications/the-world-factbook/geos/ly.html

[6] http://data.worldbank.org/indicator/SL.UEM.1524.ZS

[7] http://www.securitycouncilreport.org/monthly-forecast/2016-03/libya_24.php

[8] http:/www.theguardian.com/world/2016/mar/10/isis-libya-united-nations-gaddafi-sirtenationalistic-narrative

[9] Ibidem

[10]http://www.businessinsider.com/isis-plan-for-libya-is-falling-apart-2016-3

[11] http://uk.reuters.com/article/us-libya-security-idUKKBN0UL0XE20160107

[12] http://www.aljazeera.com/indepth/opinion/2016/02/libya-litmus-test-isil160202121022514.html

[13]***, ISIS in Libya, a Major Regional and International Threat, The Meir Amit Intelligence and Terrorism Information Centre, January 2016, p. 2.

[14] http://www.ibtimes.com/isis-al-qaeda-africa-us-commander-warns-collaborationbetween-aqim-islamic-state-2304240

[15]http://www.nytimes.com/2016/01/02/world/africa/jihadists-deepen-collaboration-innorth-africa.html

[16]http://www.ibtimes.co.uk/tunisia-least-three-killed-clashes-between-islamists-securityforces-ben-guerdane-1547925

[17]http://www.reuters.com/article/us-africa-security-us-idUSKCN0VK1ON

[18]http://www.bbc.com/news/world-middle-east-35268713

[19]http://www.dailymail.co.uk/news/article-3410631/Bomb-attack-kills-three-policemenCairo.html

[20]http://www.aljazeera.com/news/2016/03/sinai-reporting-egypt-war-terror160307061803190.html

[21]http://www.dailymail.co.uk/news/article-3523510/Sharm-El-Sheikh-appears-little-ghosttown-terror-attack-Russia-airliner-causes-lifeblood-tourists-stayaway.html\#ixzz49fGLtqJQ

[22] http://www.ibtimes.com/sudan-will-not-become-isis-territory-despite-islamic-state-groupthreat-libya-spy-2272322 